\title{
Financial Deepening, Property Rights, and Poverty: Evidence from Sub-Saharan Africa
}

\author{
Raju Jan Singh ${ }^{1}$ \\ The World Bank, United States \\ rsingh9@worldbank.org \\ Yifei Huang \\ GMO, United States \\ yifei.shea@gmo.com
}

\begin{abstract}
Recent studies on the relationship between financial development and poverty have been inconclusive. Some claim that, by allowing more entrepreneurs to obtain financing, financial development improves the allocation of capital, which has a particularly large impact on the poor. Others argue that it is primarily the rich and politically connected who benefit from improvements in the financial system. This paper looks at a sample of 37 countries in sub-Saharan Africa from 1992 through 2006. Its results suggest that financial deepening could widen income inequality and increase poverty, if not accompanied by stronger property rights. Similarly, interest rate and lending liberalization alone could be detrimental to the poor without institutional reforms, in particular stronger property rights and wider access to credit information.
\end{abstract}

JEL classification: O11, O16, G00

Keywords: financial development, poverty alleviation, income distribution, Africa

\section{INTRODUCTION}

While financial development and its effects on economic growth have attracted considerable attention in the literature, far less work has been done on the relationship between financial deepening and poverty. Theory provides conflicting predictions. Empirically, the results have been equally mixed. Yet, lack of access to finance has been argued to be one of the main factors behind persistent poverty and, more generally, the 2008 financial crisis has triggered renewed questioning on the benefits of financial development. ${ }^{2}$

Corresponding author: The World Bank, 1850 I Street NW, Washington, DC 20433, United States; email rsingh9@worldbank.org.

2 There has also been a considerable literature on the impact of growth and poverty and on how best to reduce income inequality. This paper does not try to argue that financial deepening is the most effective and direct way to reduce poverty, but only discusses a possible association between these two variables. 
Moreover, little of the research that has been done has focused on Africa, despite the prevalence of poverty in this region. Cross-country studies have tended to favor larger samples and focus on developing countries at best. While using a broader sample increases the degrees of freedom, it may also introduce unwanted heterogeneity if factors explaining income distribution or poverty differ between country groups. More recent country specific time-series analyses, while reducing the heterogeneity of the sample, have difficulties capturing the possible role of institutional factors because these change very slowly over time, but could nevertheless show critical in explaining the association between finance and poverty.

Furthermore, financial development is a complex process involving a number of intermediaries. Recent empirical studies have argued that, while necessary, financial liberalization may not be sufficient to foster an environment where the financial sector could function effectively. Institutional reforms related to property rights and creditor information are crucial. Yet the most common measures for financial development - private credit or a monetary aggregate - do not directly capture these dimensions.

This paper aims to contribute to the literature in several ways. First, it looks specifically at sub-Saharan Africa (SSA), reaching more conclusive results on the role of financial deepening in the region than studies with global or single country coverage. Second, it tries to capture explicitly the complexity of financial deepening and examines in particular the role of property rights. Its results suggest that financial deepening could widen income inequalities and increase poverty if not accompanied by stronger property rights. Similarly, liberalizing interest rates and lending alone could be detrimental to the poor without institutional reforms, in particular stronger property rights and wider access to credit information.

In what follows, Section II reviews the literature; Section III discusses the data, describes the methodology, and presents the results; and Section IV draws some conclusions.

\section{THEORETICAL BACKGROUND AND REVIEW OF THE LITERATURE}

It has been argued that lack of access to finance is one of the main factors behind persistent poverty (Levine, 2008). Because of the high unit costs of small-scale lending and other imperfections, the poor cannot borrow against future earnings to invest. Jacoby (1994), for instance, finds that lack of access to credit perpetuates poverty in Peru because poor households cannot afford to provide their children with adequate education. Jacoby and Skoufias (1997) show that households from Indian villages without access to credit markets tend to reduce their children's schooling when transitory shocks reduce their income. Similarly, Dehejia and Gatti (2003) and Beegle et al. (2003) show that child labor rates are higher in countries with poorly functioning financial systems.

Theory provides, however, conflicting predictions about the impact of financial development on income distribution and on the income of the poor. If financial markets were perfect, the availability of finance would allow individuals to fund education, training, or business opportunities based only on their talent and initiatives, not on parental wealth. As financial markets grow deeper, and access to finance improves, households that did not previously have access to finance might be the main beneficiaries. In this framework, financial development would equalize opportunities by reducing the importance of initial wealth and hence would favor the poor.

Other theories suggest that financial deepening would favor the rich. Financial institutions operate in settings where complete information is often not available. Entrepreneurs seeking financing normally have more information about their projects than their banks do. In this setting, from the viewpoint of a financial institution, projects that may have different probabilities of success are indistinguishable. This information asymmetry requires banks to screen applications so as to grant loans only to the most promising projects (Singh, 1992). 
The lender cannot rely simply on increasing the interest rate, however. As Stiglitz and Weiss (1981) demonstrated, increases in the interest rate charged on loans may adversely affect the composition of the pool of borrowers. The expected return to the lender depends on the probability of repayment, so the lender would like to be able to identify borrowers who are more likely to repay. Those who are willing to borrow at high interest rates, however, may be riskier: they are willing to borrow at high interest rates because they perceive their probability of repaying the loan to be low. For a given expected return, an increase in interest rates will induce low-risk projects to drop out first, leaving only the riskier ones in the pool.

Loan providers could invest in gathering additional information on projects that would lead to a better perception of the probability of success for a given project (Devinney, 1986; Singh, 1994, 1997). Lensink (1996) observes, for instance, that most people in SSA countries make little use of formal lending institutions: they turn to lenders in the informal sector, who solve information problems by dealing with long-time clients who usually live in the same village. This superior knowledge allows the informal lender to discriminate between high- and low-risk borrowers and charge interest accordingly. In this environment, Lensink argues, liberalizing the formal financial sector could shift funds away from the better informed informal sector and reduce access of the poor to credit.

Alternatively, lenders could require collateral, which imposes a cost if the entrepreneur defaults. As the probability of failure is greater for high-risk projects, the same amount of collateral will reduce the expected profit of these projects by more than that of less risky ones. Bester (1985) demonstrated that lenders could design attractive contracts adapted to the various qualities of borrowers, leading to perfect sorting. In this setting, the poor, who have no formal collateral, would find it difficult to reap the benefits of a larger financial sector. Financial liberalization would thus favor the rich and increase income inequality if not accompanied by reforms to deal with information problems (Banerjee and Newman, 1993; Galor and Zeira, 1993; Piketty, 1997).

Efficient exchange of information can reduce the cost of screening borrowers. In advanced countries, databases centralizing information on borrowers are often established by the private sector or maintained by central banks. These registries collect information on the standing of borrowers in the financial system and make it available to lenders. The system improves transparency, rewarding good borrowers and increasing the cost of default, and could reduce the reliance of the poor on informal finance. Detragiache et al. (2005), Djankov et al. (2005), McDonald and Schumacher (2007), and Singh et al. (2009) all show that information-sharing is associated with greater financial development.

The law and finance literature has stressed the importance of legal institutions (especially those protecting private property rights) in explaining international differences in financial development. Where legal systems enforce private property rights, support private contracts, and protect the legal rights of investors, lenders tend to be more willing to finance firms - in other words, stronger creditor rights tend to promote financial development (see Acemoglu and Johnson, 2005, Cottarelli et al., 2003, Dehesa et al., 2007, McDonald and Schumacher, 2007, Tressel and Detragiache, 2008, and Singh et al., 2009).

But how would clearer property rights help the poor? De Soto (2003) argues that the developing world has accumulated a great deal of wealth, but without legal institutions that establish and defend ownership and property rights, much of it is "dead capital" that cannot be sold or collateralized to back loans. The lack of such a legal framework makes it particularly difficult for the poor to leverage their informal ownership into capital.

Finally, the relationship between financial development and poverty may be nonlinear. Greenwood and Jovanovic (1990) present a model where income inequality first rises as the financial sector develops but then declines as more people gain access to the system. Rajan and Zingales (2003) point out that the financial system may acquire greater capacity and interest to bear the high costs of small credits as it becomes stronger and more competitive. 
Empirically, the results have been equally mixed. Beck et al. (2007), Boukhatem and Bochra (2012), Honohan (2004), and Jalilian and Kirkpatrick (2002) all find that the degree of financial intermediation has a strong positive impact on the income of the poor. Jalilian and Kirkpatrick (2002) use the ratio of bank assets to GDP to measure financial intermediation in a sample of advanced and developing economies. Beck et al. (2007), Boukhatem and Bochra (2012), and Honohan (2004), looking only at developing countries, capture the role of finance by considering private sector credit. Inoue and Hamori (2012) find similar results considering credit and deposits in a panel of 28 Indian States.

In contrast, Dollar and Kraay (2002), Kraay (2002), and more recently Fowowe and Abidoye (2012) find that financial development does not affect the poor. Dollar and Kraay (2002) examine the relationship between the average income of the poorest quintile in a sample of advanced and developing economies, and measure financial depth using the ratio of commercial bank assets to total bank assets. Fowowe and Abidoye (2012) look at private credit as a share of GDP and poverty as measured by the income of the poorest quintile and the poverty headcount in a sample of SSA countries. Kraay (2002) reaches similar results studying the association between the change in absolute poverty and the ratio of M2 to GDP in a sample of developing countries.

Finally, Guillaumont-Jeanneney and Kpodar (2008) find that the contribution of finance in alleviating poverty depends on the transmission channel. Looking at a sample of developing countries, they find a positive relationship between financial development and poverty if financial development is measured by the ratio of M3 to GDP. If private credit is used instead, the association turns out to be statistically insignificant. Their results suggest that the poor benefit primarily from the ability of the banking system to facilitate transactions and provide savings opportunities rather than reaping the benefit of greater access to credit.

More recent empirical studies based on time-series do not yield less ambiguous results. Shabhaz (2009), for instance, finds that financial development does reduce poverty in Pakistan, when it is measured as private credit as a share of GDP, a result confirmed by Khan et al. (2012). These authors show for the same country that financial deepening (broad money supply and domestic credit to the private sector) has a long-run relationship with poverty alleviation. Chemli (2014) shows that private sector credit as a share of GDP is positively associated with lower poverty in Algeria, Iran, Jordan, and Tunisia. Quartey (2005) and Odhiambo (2009b) reach similar results for Ghana and Zambia, respectively. By contrast, Ho and Odhiambo (2011) show that poverty reduction Granger causes financial development in the long run in China.

Using M2 as a share of GDP, Odhiambo (2009a) finds that financial development Granger causes poverty reduction in South Africa, while Odhiambo (2009b) shows the reverse to be true in Zambia. Similarly, Ho and Odhiambo (2011) observe in the case of China that poverty reduction Granger causes financial development in the long run, also when financial development is measured with M2 as a share of GDP. Meanwhile Aye (2013) finds no long-run relationship in the case of Nigeria between finance and poverty reduction.

Looking at 35 developing countries, Perez-Moreno (2011) finds that financial development, measured by liquid assets of the financial system as a share of GDP or by money and quasi money as a percentage of GDP, led to the reduction of moderate poverty in the1970s and the 1980s. These results disappear, however, for the 1980s and the 1990s or when financial development is measured by the ratio of private credit to GDP. Finally, using a composite index for financial development, Uddin et al. (2013) find that financial development does not seem to contribute to poverty reduction in Bangladesh, while Shabhaz and Rehman (2013) find that financial development Granger causes poverty reduction in Pakistan.

The results on income distribution seem to be equally mixed. In an analysis of income inequality, Li et al. (1998) find that financial depth contributes significantly to lowering inequality (Gini index). They measure the role of finance using the ratio of M2 to GDP in a sample of advanced and developing economies. Using private sector credit, Beck et al. (2007) and Clarke et 
al. (2006) reach similar results for a similar sample, while Fowowe and Abidoye (2012) find no association in their sample of SSA countries.

Turning to the possibility of a nonlinear relationship between financial development and poverty, Beck et al. (2007) include the squared term of private credit, but the coefficient is never significant. Clarke et al. (2006), however, find some evidence that income inequality might increase at the very early stages of financial development, as suggested by Greenwood and Jovanovic (1990) and Rajan and Zingales (2003). Their results suggest that the turning point for private credit would be about 22 percent of GDP, but they are not robust across various model specifications.

This paper will argue that differences in institutions may account for at least part of these divergent results. More particularly, this study tests the hypothesis that in countries with stronger property rights and easier access to information, financial development is associated with lower poverty rates. Because these institutions take time to develop, the recent time-series literature may not capture this dimension appropriately and a panel data approach is adopted here.

\section{EMPIRICAL ANALYSIS}

\section{A. Data}

Poverty is a complex issue. It has many faces, often changing from place to place and across time. Though it is usually defined as having insufficient resources or income, in its extreme form poverty is a lack of basic human needs, such as adequate food, clothing, housing, clean water, or health services. It is also a lack of education or opportunity, and may be associated with insecurity and fears for the future, lack of representation, and freedom.

The literature, which has generally focused on the economic aspect of poverty, mainly uses four related indicators of poverty: the headcount index, the poverty gap, the Gini coefficient, and the income of the poorest quintile. This paper adopts the same approach. The econometric analysis uses panel data for 37 SSA countries averaged over five-year periods from 1992 through $2006 .^{3}$

The headcount index measures the percentage of the population living with per capita consumption or income below the poverty line, defined as US\$1 a day. This is the most popular measure of poverty because, though arbitrary, it provides a quantifiable metric of people living in what a society at one point in time considers unacceptable conditions.

The poverty gap takes into account the distance of the poor from the poverty line. This measure characterizes how far below the poverty line lies the average income of the poor and provides some sense of distribution. Unlike the headcount index, this indicator captures a decrease or increase in the income of the poor even when it does not cross the poverty line.

The Gini coefficient, the measure most commonly used to describe income disparity, offers a comparative measure of poverty. Indicators based on the poverty line tend to describe poverty in absolute terms. Yet studies suggest that an individual's welfare depends not only on absolute income but also on how his or her income compares with that of the rest of the population. Everyone could be above the poverty line, but the income distribution might be very skewed. The Gini coefficient is derived from the Lorenz curve, with larger values indicating greater income inequality.

The income of the poorest quintile is defined as the average per capita income of the poorest 20 percent of the population.

For the right-hand-side variables, the empirical literature has typically used a banking indicator to measure the degree of financial development. As mentioned above, some researchers have used

The choice of period (1992-2006) is dictated by the availability of data on the institutional variables. 
the ratio of broad money to GDP. This measure includes, however, the liabilities of central banks as well as those of commercial banks and other financial intermediaries. It also covers credit to the government and state-owned enterprises. Others have looked at the ratio of commercial bank assets to total bank assets or to GDP, although central banks or governments could influence the flow of credit through moral suasion to favor some sectors of the economy.

More generally, broad money or bank liabilities capture the deposit-gathering activity of the financial system, but they may not be good indicators of the ability of the financial sector to fund the economy. In an environment characterized by rationing and involuntary savings or inappropriately developed institutions to support credit, looking at the credit to the private sector directly may be more appropriate. Thus some studies have turned to the amount of credit to the private sector in terms of GDP.

This indicator excludes credit to the government or state-owned enterprises, and captures the actual amount of credit channeled from savers to private firms through financial intermediaries. This paper will start by following this approach. We recognize, however, that private credit captures only the contribution of the formal financial sector, leaving out the potentially important role of the informal one, including microfinance. There are two reasons for this: (i) although the informal sector may represent a large number of institutions and loans, in the aggregate the credit it offers is usually dwarfed by that of formal financial institutions; (ii) when informal financial arrangements become economically substantive, they tend to be integrated into the formal sector.

The research reviewed above suggests that developments in private credit are associated not only with a liberalization of interest rates but also with progress in strengthening property rights and widening access to creditor information. Following this literature, this paper examines the following institutional variables:

The financial liberalization index, constructed for SSA countries by McDonald and Schumacher (2007) based on an earlier study by Gelbard and Leite (1999). This aggregate index, bounded between 0 and 100, captures whether or not interest rates are liberalized, the number of years real lending and deposit rates have been positive, and the existence of a significant informal financial sector and directed credit allocation mechanisms.

The property rights index measures the ability of individuals to accumulate private property, secured by clear laws that the state fully enforces. It ranges between 0 and 100 and is compiled annually by the Heritage Foundation.

The information-sharing index, a dummy variable indicating the presence of either public or private credit registries, is taken from Djankov et al. (2005). A credit registry is defined as a database managed by a government agency or a private organization that collects information on the standing of borrowers in the financial system and makes it available to present and potential lenders.

Finally, in line with Dollar and Kraay (2002), we include a set of control variables that are commonly used as factors determining poverty: overall income per capita, to capture the contribution of economic development (GDP per capita); growth of the consumer price index, to control for the macroeconomic environment (inflation); the general legal environment, to assess institutional quality (rule of law); and the sum of exports and imports as a share of GDP, to capture the degree of international openness (trade openness).

Tables 1 and 2 present descriptive statistics and correlations for the sample period. Table 1 shows that there are wide cross-country differences in the prevalence of poverty. Similarly, the countries in the sample demonstrate important variations in financial sector development as measured by the private credit-to-GDP ratio. Annex I shows the average values of key variables per country and Annex II indicates the various data sources. 
Table 1

Descriptive Statistics, 1992-2006

\begin{tabular}{lccccc}
\hline \multicolumn{1}{c}{ Variable } & Observations & Mean & $\begin{array}{c}\text { Standard } \\
\text { deviation }\end{array}$ & Minimum & Maximum \\
\hline Headcount index $(\log )$ & 70 & 3.62 & 0.66 & 0.59 & 4.39 \\
Poverty gap $(\log )$ & 70 & 2.56 & 0.91 & -1.11 & 3.93 \\
Gini coefficient $(\log )$ & 76 & 3.81 & 0.17 & 3.50 & 4.29 \\
Income of the poorest quintile $(\log )$ & 68 & 2.50 & 0.52 & 0.90 & 3.69 \\
Private credit over GDP $(\log )$ & 76 & -2.63 & 1.69 & -9.34 & -0.44 \\
Financial liberalization $(\log )$ & 59 & 4.02 & 0.57 & 1.50 & 4.62 \\
GDP per capita $(\log )$ & 76 & 5.87 & 0.86 & 4.48 & 8.28 \\
Inflation (log) & 76 & 0.12 & 0.16 & -0.02 & 1.12 \\
Rule of law & 76 & -0.63 & 0.60 & -1.77 & 0.81 \\
Trade openness $(\log )$ & 76 & 4.14 & 0.48 & 2.98 & 5.17 \\
Property rights $(\log )$ & 70 & 3.70 & 0.41 & 2.30 & 4.25 \\
Information sharing & 76 & 0.56 & 0.50 & 0.00 & 1.00 \\
\hline \hline
\end{tabular}

Consistent with previous research, private credit to GDP is correlated positively with GDP per capita. It is also negatively correlated with the headcount index and the poverty gap, and positively with the income of the poorest quartile. Interestingly, there is a small positive correlation between private credit and the Gini coefficient. This result stems from the fact that changes in income distribution are not necessarily reflected in changes in absolute poverty. Changes in the Gini coefficient may be associated, for instance, with income redistributed from the top to the middle class without affecting the bottom quintile (Deininger and Squire, 1996). While the two poverty indicators based on the poverty line - the headcount index and the poverty gap - are strongly positively correlated, there is no strong relation between these two indicators and the Gini coefficient.

Table 2

Correlation Matrix

\begin{tabular}{|c|c|c|c|c|c|c|c|c|c|c|c|c|c|}
\hline Variable & & 1 & 2 & 3 & 4 & 5 & 6 & 7 & 8 & 9 & 10 & 11 & 12 \\
\hline Headcount index (log) & 1 & 1.00 & & & & & & & & & & & \\
\hline Poverty gap (log) & 2 & 0.98 & 1.00 & & & & & & & & & & \\
\hline Gini coefficient (log) & 3 & -0.00 & 0.09 & 1.00 & & & & & & & & & \\
\hline Income of poorest $20 \%(\log )$ & 4 & -0.85 & -0.91 & -0.29 & 1.00 & & & & & & & & \\
\hline Private credit (log) & 5 & -0.37 & -0.39 & 0.06 & 0.40 & 1.00 & & & & & & & \\
\hline Financial liberalization (log) & 6 & -0.17 & -0.16 & -0.02 & 0.21 & 0.05 & 1.00 & & & & & & \\
\hline GDP per capita (log) & 7 & -0.61 & -0.56 & 0.51 & 0.37 & 0.31 & 0.24 & 1.00 & & & & & \\
\hline Inflation (log) & 8 & 0.19 & 0.25 & 0.28 & -0.32 & -0.17 & -0.28 & -0.01 & 1.00 & & & & \\
\hline Rule of law & 9 & -0.06 & -0.06 & 0.23 & -0.04 & 0.23 & 0.17 & 0.31 & -0.24 & 1.00 & & & \\
\hline Trade openness (log) & 10 & -0.12 & -0.01 & 0.39 & -0.10 & 0.04 & 0.24 & 0.44 & 0.28 & 0.21 & 1.00 & & \\
\hline Property rights (log) & 11 & -0.08 & -0.07 & 0.20 & -0.01 & 0.35 & -0.12 & 0.20 & -0.04 & 0.60 & 0.15 & 1.00 & \\
\hline Information sharing & 12 & -0.12 & -0.16 & -0.11 & 0.20 & 0.00 & 0.26 & 0.08 & -0.17 & -0.22 & -0.16 & -0.50 & 1.00 \\
\hline
\end{tabular}




\section{B. Methodology and Main Results}

To examine the incidence of financial development on poverty, two exercises will be carried out. First, the paper will study the association between the different measures of poverty and credit to the private sector, allowing for a nonlinear relationship with financial development. Our hypothesis is that stronger property rights are not only related to lower poverty (a negative and significant coefficient for the financial development variable) but also enhance the association of financial deepening and poverty (a negative and significant coefficient on the interaction term).

The relationship between financial development and our measures of poverty could face an endogeneity problem, stemming from measurement errors, omitted variables or potential reverse causality, as some of the results of the recent time-series literature would suggest. One could argue, for instance, that as poverty drops, a larger share of the population becomes bankable, deepening the financial sector through an increase in demand for financial services.

To try to deal with these issues, we used the Feasible Generalized Least Squares (FGLS) method, including country and time random effects. This approach is also more appropriate for our panel data than fixed effect models because the time span is short; for each country, data are available from at most three periods. Furthermore, a Hausman test failed to reject the null hypothesis that the right-hand-side variables are not correlated with the error term, favoring the random-effects specification. To test our results, we also used the lagged values for financial development and income per capita as instruments.

A standard model along the lines of Dollar and Kraay (2002) and Clarke et al. (2006) will be used, where poverty depends on financial development, and a set of economic and institutional conditions. We also introduce an index on property rights (PR) and an interaction term with our financial development variable. The model specification is as follows:

$$
\log \left(P_{i, t}\right)=\alpha_{0}+f\left(F D_{i, t}\right)+\alpha_{2} \cdot \log \left(P R_{i, t}\right)+\alpha_{3} \cdot \log \left(F D_{i, t}\right) \times \log \left(P R_{i, t}\right)+\alpha_{4} \cdot X_{i, t}+u_{i}+v_{t}+\varepsilon_{i, t}
$$

where $P_{i, t}$ is one of the poverty indicators in country $i$ at time $t . F D_{i, t}$ represents private credit over GDP, $X_{i, t}$ stands for a set of control variables, $u_{i}$ and $v_{t}$ are the country and time random effects, respectively, and $\varepsilon_{i, t}$ is the error term and:

$$
f\left(F D_{i, t}\right)=c_{1} \cdot \log \left(F D_{i, t}\right)+c_{2} \cdot\left(\log \left(F D_{i, t}\right)\right)^{2}
$$

As a second step, to enrich our analysis of financial development, we replace private creditto-GDP with the indices reflecting financial liberalization and the degree of information-sharing. The model specification becomes:

$$
\log \left(P_{i, t}\right)=\alpha_{0}+\alpha_{1} \cdot F L_{i, t}+\alpha_{2} \cdot \log \left(P R_{i, t}\right)+\alpha_{3} \cdot \text { Info_shar }_{i, t}+\alpha_{4} \cdot X_{i, t}+u_{i}+v_{t}+\varepsilon_{i, t}
$$

The results are presented in Tables 3-6. Turning first to the control variables, we find a significant negative association of GDP per capita and poverty, whether measured by the headcount index, the poverty gap, or the income of the poorest quintile. Interestingly, the results also suggest a significant positive correlation between GDP per capita and the Gini coefficient, which would indicate that income inequality is higher in the richer SSA countries. This could be due to the Kuznets effect, which states that in the early stages of development, higher GDP per capita could be correlated with greater income inequality. The results also indicate that inflation is consistently detrimental for the poor. Trade openness does not have a significant impact on any of the poverty indicators. There also seems to be a positive correlation between the rule of law and poverty. 
Consistent with Clarke et al. (2006), the results from model 1 (see Tables 3-6, columns 1 and 2) suggest a nonlinear relation between financial deepening and poverty. Once instrumented, private sector credit is significantly associated with higher levels of poverty or lower levels of income for the poorest quintile. As the financial sector develops, however, this negative association tends to fade away, the coefficient of the square term of $\log \left(F D_{i, t}\right)$ being significant and of the opposite sign. The association with the Gini coefficient is, however, not significant.

Table 3

Dependent Variable: Headcount Index

Feasible Generalized Least Squares

(1)

(2 IV)

(3)

\begin{tabular}{|c|c|c|c|}
\hline Private Credit / GDP (log) & $\begin{array}{l}0.052 \\
(0.29)\end{array}$ & $\begin{array}{l}0.467 \\
(4.23)^{* * *}\end{array}$ & \\
\hline$(\text { Private Credit / GDP }(\log ))^{2}$ & $\begin{array}{l}-0.026 \\
(3.52)^{* * *}\end{array}$ & $\begin{array}{l}-0.016 \\
(1.90)^{*}\end{array}$ & \\
\hline Financial Liberalization (log) & & & $\begin{array}{c}0.286 \\
(1.97)^{* *}\end{array}$ \\
\hline GDP per capita (\$US, log) & $\begin{array}{l}-0.423 \\
(8.84)^{* * *}\end{array}$ & $\begin{array}{l}-0.547 \\
(7.38)^{* * *}\end{array}$ & $\begin{array}{l}-0.539 \\
(8.94)^{* * *}\end{array}$ \\
\hline Inflation $(\log )$ & $\begin{array}{l}0.241 \\
(1.39)\end{array}$ & $\begin{array}{l}0.544 \\
(2.81)^{* * *}\end{array}$ & $\begin{array}{l}0.539 \\
(2.19)^{* *}\end{array}$ \\
\hline Rule of Law & $\begin{array}{l}0.176 \\
(1.86)^{*}\end{array}$ & $\begin{array}{l}0.240 \\
(2.18)^{* *}\end{array}$ & $\begin{array}{l}0.052 \\
(0.39)\end{array}$ \\
\hline Trade Openness (log) & $\begin{array}{l}0.059 \\
(0.71)\end{array}$ & $\begin{array}{l}0.024 \\
(0.25)\end{array}$ & $\begin{array}{l}0.120 \\
(1.31)\end{array}$ \\
\hline Property Rights (log) & $\begin{array}{c}-0.302 \\
(1.74)^{*}\end{array}$ & $\begin{array}{l}-0.504 \\
(2.63)^{* * *}\end{array}$ & $\begin{array}{c}-0.293 \\
(1.81)^{*}\end{array}$ \\
\hline Interaction (lpror, lpred) & $\begin{array}{l}-0.123 \\
(2.62)^{* * *}\end{array}$ & $\begin{array}{l}-0.211 \\
(4.47)^{* * *}\end{array}$ & \\
\hline Information sharing & & & $\begin{array}{l}-0.140 \\
(1.85)^{*}\end{array}$ \\
\hline Constant & $\begin{array}{l}6.180 \\
(7.38)^{* * *}\end{array}$ & $\begin{array}{l}7.781 \\
(9.11)^{* * *}\end{array}$ & $\begin{array}{l}6.046 \\
(6.34)^{* * *}\end{array}$ \\
\hline Observations & 66 & 43 & 57 \\
\hline Number of countries & 34 & 31 & 28 \\
\hline Adjusted R2 & 0.380 & 0.713 & 0.638 \\
\hline Chi square (Walden test) & 306.09 & 1406.40 & 147.02 \\
\hline
\end{tabular}

Notes: Data are averaged over five years. Absolute value of $\mathrm{z}$ statistics in parentheses; ${ }^{*}$ significant at $10 \% ;{ }^{* *}$ significant at $5 \% ;{ }^{* * *}$ significant at $1 \%$.

We next examine the role of property rights. The results indicate that the coefficients on both the property rights variable and its interaction term with the financial development indicator are generally significant: negative when the dependent variable is the headcount index, the poverty gap, or the Gini coefficient, and positive when the response variable is the income of the poor. These results suggest that stronger property rights significantly enhance the association between 
financial development and poverty reduction. As we expected, the poor benefit more from financial deepening in countries with secure property rights, which allow them to use collateral for better access to credit. The use of instrumental variables does not alter the results.

Table 4

Dependent Variable: Poverty Gap

Feasible Generalized Least Squares

(1)

Private Credit / GDP $(\log )$

(Private Credit / GDP $(\log ))^{2}$

Financial Liberalization $(\log )$

GDP per capita (\$US, log)

Inflation $(\log )$

Rule of Law

Trade Openness $(\log )$

Property Rights $(\log )$

Interaction (lpror, lpred)

Information sharing

Constant

Observations

Number of countries

Adjusted R2

Chi square (Walden test)
(2 IV)

(3)

$\begin{array}{ll}0.101 & 0.559 \\ (0.37) & (4.75)^{* * *} \\ -0.045 & -0.024 \\ (4.80)^{* * *} & (2.02)^{* *}\end{array}$

0.411

$(1.75)^{*}$

$-0.708$

$(8.39)^{* * * *}$

0.766

$(2.12)^{* *}$

0.019

(0.11)

0.396

$(2.78)^{* * *}$

$-0.500$

$(2.07)^{* *}$

$-0.277$

$(5.18)^{* * *}$

$-0.295$

$(2.37)^{* *}$

6.967

5.022

$(7.86)^{* * *}$

$(3.49)^{* * *}$

$(5.32)^{* * *}$

43

57

31

28

0.399

0.808

0.297

913.21

176.12

Notes: Data are averaged over five years. Absolute value of $\mathrm{z}$ statistics in parentheses; ${ }^{*}$ significant at $10 \% ;{ }^{* *}$ significant at $5 \% ;{ }^{* * *}$ significant at $1 \%$.

As the second step, we looked at determinants of private credit and their impact on poverty and income distribution. The results (see Tables 3-6, column 3) suggest that liberalizing interest rates and lending alone could be detrimental to the poor, irrespective of the indicator used to assess poverty. The coefficient on the financial liberalization index appears significant in all specifications: positive for the headcount index, the poverty gap, and the Gini coefficient, and negative for the income of the poorest quintile. By contrast, strengthening the institutional framework, such as allowing wider access to credit information and enhancing property rights, is generally associated with a reduction in poverty. 
To test for the robustness of the results:

- The rule of law variable was taken out because of its correlation with the property rights index, but the results were not significantly different (see Annex III, Table A1).

- We changed our sample from SSA countries to a dataset including low-income countries only. The results were unchanged (see Annex III, Tables A2-A5).

- We also tested for the potential influence of outliers by dropping from the sample the observations related to Botswana, Gabon, and South Africa. The results were also unaffected (see Annex III, Tables A6-A9).

Table 5

Dependent Variable: Gini Coefficient

Feasible Generalized Least Squares

Financial Liberalization $(\log )$

GDP per capita (\$US, log)

Inflation $(\log )$

Rule of Law

Trade Openness $(\log )$

Property Rights (log)

Interaction (lpror, lpred)

Information sharing

Constant

Observations

Number of countries

Adjusted R2

Chi square (Wald test)
(1)

$\begin{array}{rr}0.026 & -0.075 \\ (0.48) & (1.22) \\ -0.004 & 0.002 \\ (1.45) & (0.64)\end{array}$

3.143

$(14.17)^{* * *}$

(2 IV)

(3)

$(0.64)$

$\begin{array}{ll} & \\ 0.078 & 0.066 \\ (4.78)^{* * *} & (3.32)^{* * *} \\ 0.182 & 0.238 \\ (5.37)^{* * *} & (4.81)^{* * *} \\ 0.040 & -0.025 \\ (1.71)^{*} & (0.88) \\ 0.021 & 0.011 \\ (0.81) & (0.42) \\ -0.003 & 0.173 \\ (0.06) & (3.48)^{* * *} \\ -0.023 & 0.023 \\ (1.67)^{*} & (1.50)\end{array}$

70
36
0.746
894.11

43

31

0.026

$(1.66)^{*}$

0.058

$(4.46)^{* * *}$

0.180

$(4.91)^{* * *}$

$-0.005$

$(0.27)$

0.065

$(3.08)^{* * *}$

0.062

(1.48)

$-0.009$

(0.26)

2.834

$(16.56)^{* * *}$

$(11.56)^{* * *}$

61

30

0.451

247.03

Notes: Data are averaged over five years. Absolute value of z statistics in parentheses; ${ }^{*}$ significant at $10 \% ;{ }^{* *}$ significant at $5 \%$; ${ }^{* * *}$ significant at $1 \%$. 
Table 6

Dependent Variable: Income of the Poorest Quintile

Feasible Generalized Least Squares

(1)

(2 IV)

(3)

\begin{tabular}{|c|c|c|c|}
\hline Private Credit / GDP (log) & $\begin{array}{r}-0.135 \\
(0.66)\end{array}$ & $\begin{array}{l}-0.335 \\
(2.38)^{* *}\end{array}$ & \\
\hline$(\text { Private Credit / GDP }(\log ))^{2}$ & $\begin{array}{l}0.019 \\
(3.27)^{* * *}\end{array}$ & $\begin{array}{l}0.012 \\
(1.81)^{*}\end{array}$ & \\
\hline Financial Liberalization (log) & & & $\begin{array}{l}-0.222 \\
(3.04)^{* * *}\end{array}$ \\
\hline GDP per capita (\$US, log) & $\begin{array}{l}0.200 \\
(4.30)^{* * *}\end{array}$ & $\begin{array}{l}0.251 \\
(4.85)^{* * *}\end{array}$ & $\begin{array}{l}0.354 \\
(7.94)^{* * *}\end{array}$ \\
\hline Inflation (log) & $\begin{array}{l}-0.496 \\
(6.33)^{* * *}\end{array}$ & $\begin{array}{l}-0.702 \\
(3.97)^{* * *}\end{array}$ & $\begin{array}{l}-0.665 \\
(3.72)^{* * *}\end{array}$ \\
\hline Rule of Law & $\begin{array}{l}-0.166 \\
(2.14)^{* *}\end{array}$ & $\begin{array}{l}-0.217 \\
(2.34)^{* *}\end{array}$ & $\begin{array}{r}-0.126 \\
(1.25)\end{array}$ \\
\hline Trade Openness (log) & $\begin{array}{r}-0.090 \\
(1.20)\end{array}$ & $\begin{array}{r}-0.089 \\
(1.23)\end{array}$ & $\begin{array}{l}-0.303 \\
(6.06)^{* * *}\end{array}$ \\
\hline Property Rights (log) & $\begin{array}{l}0.236 \\
(1.28)\end{array}$ & $\begin{array}{l}0.341 \\
(2.37)^{* *}\end{array}$ & $\begin{array}{l}0.344 \\
(1.75)^{*}\end{array}$ \\
\hline Interaction (lpror, lprcd) & $\begin{array}{l}0.128 \\
(2.45)^{* *}\end{array}$ & $\begin{array}{l}0.165 \\
(4.04)^{* * *}\end{array}$ & \\
\hline Information sharing & & & $\begin{array}{c}0.150 \\
(1.65)^{*}\end{array}$ \\
\hline Constant & $\begin{array}{l}1.603 \\
(2.07)^{* *}\end{array}$ & $\begin{array}{l}0.879 \\
(1.44)\end{array}$ & $\begin{array}{l}1.426 \\
(1.56)\end{array}$ \\
\hline Observations & 64 & 41 & 55 \\
\hline Number of countries & 34 & 31 & 28 \\
\hline Adjusted R2 & 0.726 & 0.866 & 0.408 \\
\hline Chi square (Wald test) & 2979.11 & 1781.65 & 635.94 \\
\hline
\end{tabular}

Notes: Data are averaged over five years. Absolute value of $\mathrm{z}$ statistics in parentheses $;{ }^{*}$ significant at $10 \% ;{ }^{* *}$ significant at $5 \% ;{ }^{* * *}$ significant at $1 \%$.

\section{SUMMARY AND CONCLUSIONS}

While financial development and its effects on economic growth have attracted considerable attention in the literature, far less work has been done on the relationship between financial deepening and poverty. Theory provides conflicting predictions and the empirical results have been mixed. By focusing on SSA countries and introducing institutional variables such as property rights, we hoped to reach more conclusive results.

Our estimations suggest that financial deepening could be associated with less poverty and income disparities in SSA countries, but for this association to materialize, financial development needs to be accompanied by stronger property rights. In the absence of clearly defined and enforced 
property rights, wider access to credit is associated with lower income for the poorest quintile and higher poverty. Similarly, liberalizing interest rates or lending alone could be detrimental for the poor without institutional reforms (property rights, credit information).

The main policy implications are that fostering an expansion in credit to the private sector is not enough to reduce poverty and income inequalities. If financial development is to be propoor, liberalization needs to be accompanied by efforts to expand credit information and firm up creditor rights. These are, however, equally complex processes.

The coverage of existing credit bureaus should be extended to include as much information as possible on the repayment profile of customers. This should be achieved while preserving privacy and safeguarding sensitive information. Strengthening creditor rights would require changes in the laws governing debt collection and collateral. Good legislation on debt recovery would depend in turn on efficient property registration and land surveying in both urban and rural areas. Land rights are, however, very often defined by customary law in rural areas. While moving towards more formal property registration care should be taken not to undermine customary rights and transfer property unintentionally to richer segments of the population. Finally, it would be vital to reform courts to improve enforcement.

Our discussion assumed up to now that appropriate incentives were in place for credit officers to use improved property rights and credit information to extend loans wisely. The 2008 financial crisis has illustrated, however, that this assumption should not be taken for granted. Weak bank supervision and strong incentives to take excessive risks may extend credit to people beyond levels justified by their creditworthiness. Recent literature shows that financial crises could be especially detrimental to poorer households, wiping away any benefits that wider credit access could have offered them. Against this background, ensuring appropriate bank supervision and prudential regulations would be equally called for in order to achieve a sound and stable development of the financial sector.

Further work to refine the analysis provided in this paper could thus include the role of bank supervision and prudential regulations in reducing the risk of financial crises and their detrimental effects on poverty. Case studies of countries where improvements in property rights have been successfully achieved would also be useful. Further empirical studies using multi-dimensional poverty indicators and longer time-series, as these become available, could be carried out to confirm the results presented in this paper. Furthermore, possible future research could include an extension to include micro-finance where data are available.

\section{Ackowledgements}

The paper was prepared when Raju Jan Singh was a Senior Economist and Yifei Huang a summer intern at the African Department of the International Monetary Fund. The opinions expressed in this paper are those of the authors and do not necessarily reflect those of the International Monetary Fund, the World Bank, or Grantham, Mayo, Van Otterloo \& Co., LLC. We thank Andrew Berg, Asli Demirguc-Kunt, Jiro Honda, Roland Kpodar, Mauro Mecagni, Brett Rayner, Gonzalo Salinas, and three anonymous referees, as well as participants at the IMF African Department Research Seminar, the $9^{\text {th }}$ Louis-André Gérard-Varet Conference at the University of the Mediterranean, and the World Bank FPD Academy for their useful comments. 


\section{References}

Acemoglu, D., S. Johnson (2005) Unbundling institutions. Journal of Political Economy 113, pp. 949-995. http:// dx.doi.org/10.1086/432166

Aye, G.C. (2013) Causality between financial deepening, economic growth and poverty reduction in Nigeria. The Business and Management Review 3, pp 1-12.

Banerjee, A.V., A.F. Newman (1993) Occupational choice and the process of development. Journal of Political Economy 101, pp. 274-298. http://dx.doi.org/10.1086/261876.

Beck, T., A. Demirguc-Kunt, R. Levine (2007) Finance, inequality and the poor. Journal of Economic Growth 12 , pp. 27-49. http://dx.doi.org/10.1007/s10887-007-9010-6

Beegle, K., R. Dehejia, R. Gatti (2003) Child labor, crop shocks, and credit constraints. NBER Working Paper 10088, Cambridge, MA: National Bureau of Economic Research. http://dx.doi.org/10.3386/w10088

Bester, H. (1985) Screening vs. rationing in credit markets with adverse selection. American Economic Review 75, pp. $850-855$.

Boukhatem J., M. Bochra (2012) Effets directs du développement financier sur la pauvreté : validation empirique sur un panel de pays à bas et moyen revenu. Mondes en Développement $\mathrm{n}^{\circ} 160$, pp. 133-148. http://dx.doi. org/10.3917/med.160.0133

Chemli L. (2014) The nexus among financial development and poverty reduction: an application of ARDL approach from the MENA region. Journal of Economics and Development Studies 2, pp. 125-134. http://dx.doi. org/10.15640/jeds.v2n4a9

Clarke, G., L.C. Xu, H. Zou (2006) Finance and income inequality: what do the data tell us? Southern Economic Journal 72, pp. 578-596. http://dx.doi.org/10.2307/20111834

Cottarelli, C., G. Dell'Ariccia, I. Vladkova-Hollar (2003) Early birds, late risers, and sleeping beauties: bank credit growth to the private sector in Central and Eastern Europe and the Balkans. IMF Working Paper WP/03/213, Washington: International Monetary Fund. http://dx.doi.org/10.5089/9781451874969.001

de Soto, H. (2003) The Mystery of Capital: Why Capitalism Triumphs in the West and Fails Everywhere Else, New York: Basic Books. http://dx.doi.org/10.5840/chesterton2003294122

Dehejia, R., R. Gatti (2003) Child labor: the role of income variability and credit constraints across countries. NBER Working Paper 9018, Cambridge, MA: National Bureau of Economic Research. http://dx.doi. org/10.1086/428714

Dehesa, M., P. Druck, A. Plekhanov (2007) Relative price stability, creditor rights, and financial deepening. IMF Working Paper WP/07/139, Washington: International Monetary Fund. http://dx.doi.org/10.5089/ 9781451867039.001

Deininger, K., L. Squire (1996) A new data set measuring income inequality. The World Bank Economic Review 10, pp. 565-591. http://dx.doi.org/10.1093/wber/10.3.565

Detragiache, E., P. Gupta, T. Tressel (2005) Finance in lower-income countries: an empirical exploration. IMF Working Paper WP/05/167, Washington: International Monetary Fund. http://dx.doi.org/10.5089/9781451861860.001

Devinney, T.M. (1986) Rationing in a Theory of the Banking Firm, Berlin, Springer-Verlag. http://dx.doi.org/10. 1007/978-3-642-82649-8

Djankov, S., C. McLiesh, A. Shleifer (2005) Private credit in 129 countries. National Bureau of Economic Research Working Paper No. 11078, Cambridge, MA: NBER. http://dx.doi.org/10.2139/ssrn.637301

Dollar, D., A. Kraay (2002) Growth is good for the poor. Journal of Economic Growth 7, pp. 195-225. http://dx.doi. org/10.1023/a:1020139631000

Fowowe, B., B. Abidoye (2012) A quantitative assessment of the effect of financial development on poverty in African countries. Department of Economics, University of Ibadan, Nigeria. http://dx.doi.org/10.1111/j.1467 -9957.2012.02302.x

Galor, O., J. Zeira (1993) Income distribution and macroeconomics. Review of Economic Studies 60, pp. 35-52. http://dx.doi.org/10.2307/2297811

Gelbard, E., S.P. Leite (1999) Measuring financial development in sub-Saharan Africa. IMF Working Paper, 99/105, Washington: International Monetary Fund. http://dx.doi.org/10.5089/9781451852806.001

Greenwood, J., B. Jovanovic (1990) Financial development, growth, and the distribution of income. Journal of Political Economy 98, pp. 1076-1107. http://dx.doi.org/10.1086/261720

Guillaumont-Jeanneney, S., K. Kpodar (2008) Financial development and poverty reduction: can there be a benefit without a cost? IMF Working Paper, WP/08/62, Washington: International Monetary Fund. http://dx.doi. org/10.5089/9781451869248.001

Ho, S-Y., M.N. Odhiambo (2011) Finance and poverty reduction in China: an empirical investigation. International Business \& Economics Research Journal 10, pp. 103-114.

Honohan, P. (2004) Financial development, growth and poverty: how close are the links? World Bank Policy Research Working Paper 2103, Washington: World Bank. http://dx.doi.org/10.1596/1813-9450-3203 
Inoue, T., S. Hamori (2012) How has financial deepening affected poverty reduction in India? Empirical analysis using state-level panel data. Applied Financial Economics 22, pp. 395-403. http://dx.doi.org/10.1080/09603 107.2011.613764

Jacoby, H. (1994) Borrowing constraints and progress through school: evidence from Peru. Review of Economics and Statistics 76, pp. 151-160. http://dx.doi.org/10.2307/2109833

Jacoby, H., E. Skoufias (1997) Risk, financial markets, and human capital. Review of Economic Studies 64, pp. 311-335. http://dx.doi.org/10.2307/2971716

Jalilian, H., C. Kirkpatrick (2002) Financial development and poverty reduction in developing countries. International Journal of Finance and Economics 7, pp. 97-108. http://dx.doi.org/10.1002/ijfe.179

Khan, A.D., I. Ahmad, W.U. Jan (2012) Financial development and poverty alleviation: time series evidence from Pakistan. World Applied Sciences Journal 18, pp. 1576-1581.

Kraay, A. (2004) When is growth pro-poor? Cross-country evidence. IMF Working Paper, 04/47, Washington: International Monetary Fund. http://dx.doi.org/10.5089/9781451846676.001

Lensink, R. (1996) The allocative efficiency of the formal versus the informal financial sector. Applied Economics Letter 3, pp. 163-165. http://dx.doi.org/10.1080/135048596356582

Levine R. (2008) Finance and the poor. The Manchester School 76, pp. 1-13. http://dx.doi.org/10.1111/j.1467-9957. 2008.01078.x

Li, H., L. Squire, H. Zou (1998) Explaining international intertemporal variations in income inequality. Economic Journal 108, pp. 26-43. http://dx.doi.org/10.1111/1468-0297.00271

McDonald, C., L. Schumacher (2007) Financial deepening in sub-Saharan Africa: empirical evidence on the role of creditor rights protection and information sharing. IMF Working paper, WP/07/203, Washington: International Monetary Fund. http://dx.doi.org/10.5089/9781451867671.001

Odhiambo, N.M. (2009a) Finance-growth-poverty nexus in South Africa: a dynamic causality linkage. Journal of Socio-Economics 38, pp. 320-325. http://dx.doi.org/10.1016/j.socec.2008.12.006

Odhiambo, N.M. (2009b) Financial deepening and poverty reduction in Zambia: an empirical investigation. International Journal of Social Economics 37, pp. 41-53. http://dx.doi.org/10.1108/03068291011006166

Perez-Moreno, S. (2011) Financial development and poverty in developing countries: a causal analysis. Empirical Economics 41, pp. 57-80. http://dx.doi.org/10.1007/s00181-010-0392-5

Piketty, T. (1997) The dynamics of wealth distribution and the interest rate with credit rationing. Review of Economic Studies 64, pp. 173-189. http://dx.doi.org/10.2307/2971708

Quartey, P. (2005) Financial sector development, savings mobilization and poverty reduction in Ghana. UNU-WIDER Research Paper No.2005/71, Helsinki: UNU World Institute for Development Economics Research. http:// dx.doi.org/10.4337/9781845424602.00008

Rajan, R. G., L. Zingales (2003) Banks and markets: the changing character of European finance. CEPR Discussion Paper No. 3865, London: Centre for Economic Policy Research. http://dx.doi.org/10.3386/w9595

Shahbaz, M. (2009) Financial performance and earnings of poor people: a case study of Pakistan. Journal of Yasar University 4, pp. 2557-2572.

Shahbaz, M., I.U. Rehman (2013) Multivariate-based Granger causality between financial deepening and poverty: the case of Pakistan. MPRA paper, No 50834, Munich. http://dx.doi.org/10.1007/s11135-013-9952-z

Singh, R. (1992) An imperfect information approach to the structure of the financial system. UNCTAD Discussion Paper No. 46, Geneva: UNCTAD.

Singh, R. (1994) Bank credit, small firms, and the design of a financial system for Eastern Europe, UNCTAD Discussion Paper No. 86, Geneva: UNCTAD.

Singh, R. (1997) Banks, growth, and geography. UNCTAD Discussion Paper No. 127, Geneva: UNCTAD. http:// dx.doi.org/10.2139/ssrn.1479834

Singh, R., K. Kpodar, D. Ghura (2009) Financial deepening in the CFA franc zone: the role of institutions. IMF Working Paper, WP/09/113, Washington: International Monetary Fund. http://dx.doi.org/10.5089/9781451872606.001

Stiglitz, J.E., A. Weiss (1981) Credit rationing in markets with imperfect information. American Economic Review 71, pp. 393-410.

Uddin G.S., M. Shahbaz, M.E. Arouri (2013) Financial development and poverty reduction nexus: a cointegration and causality analysis in Bangladesh. MPRA Paper No. 49264, Munich. http://dx.doi.org/10.1016/j. econmod.2013.09.049

Tressel, T., E. Detragiache (2008) Do financial sector reforms lead to financial development? Evidence from a new dataset. IMF Working Paper WP/08/265, Washington: International Monetary Fund. http://dx.doi. org/10.5089/9781451871234.001 


\section{ANNEXES}

\section{Key Variables by Country - Average Values}

\begin{tabular}{|c|c|c|c|c|c|c|c|c|c|c|c|}
\hline Country & 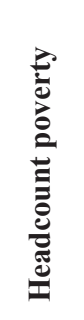 & 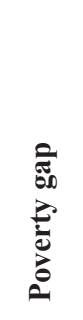 & 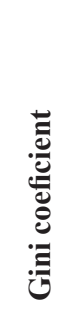 & 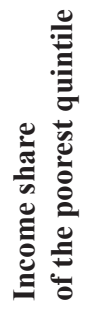 & 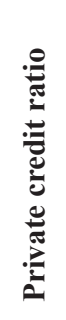 & 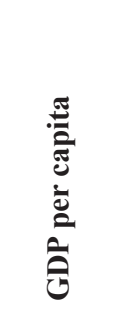 & 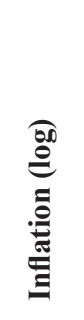 & 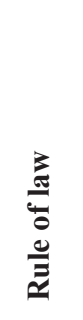 & 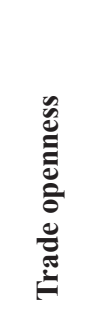 & 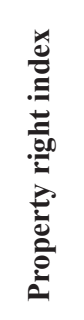 & 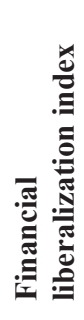 \\
\hline Angola & 46.7 & 24.8 & 58.6 & 7.2 & 0.0 & 690.4 & 1.41 & -1.5 & 140.2 & 30.0 & 43.5 \\
\hline Benin & 33.5 & 9.5 & 38.6 & 19.4 & 0.1 & 303.3 & 0.06 & -0.4 & 43.9 & 39.1 & 67.5 \\
\hline Botswana & 22.9 & 7.4 & 61.0 & 12.7 & 0.1 & 3390.1 & 0.09 & 0.6 & 87.0 & 70.0 & 82.5 \\
\hline Burkina Faso & 54.0 & 20.4 & 44.0 & 10.9 & 0.1 & 232.7 & 0.04 & -0.5 & 34.9 & 37.3 & 84.5 \\
\hline Burundi & 74.2 & 31.7 & 36.3 & 8.8 & 0.2 & 117.4 & 0.11 & -1.3 & 32.9 & 30.0 & .. \\
\hline Cameroon & 30.8 & 9.1 & 45.7 & 16.9 & 0.1 & 672.3 & 0.04 & -1.2 & 41.3 & 31.7 & 53.5 \\
\hline Cape Verde & 13.3 & 3.1 & 50.5 & 21.7 & 0.3 & 1111.2 & 0.03 & 0.5 & 81.0 & 62.7 & 73.5 \\
\hline Central African Rep. & 64.5 & 36.1 & 55.1 & 6.3 & 0.0 & 239.3 & 0.04 & -1.3 & 37.3 & 38.0 & 47.0 \\
\hline Chad & 49.2 & 18.1 & 39.8 & 11.8 & 0.0 & 201.1 & 0.05 & -1.1 & 62.3 & 30.0 & .. \\
\hline Congo, Dem. Rep. & 47.8 & 18.2 & 44.4 & 10.9 & 0.0 & 102.6 & 1.61 & -1.9 & 49.9 & 26.7 & 50.0 \\
\hline Congo, Rep. & 43.4 & 16.3 & 47.3 & 11.1 & 0.1 & 978.4 & 0.06 & -1.3 & 128.1 & 26.4 & 63.5 \\
\hline Cote d'Ivoire & 12.5 & 2.8 & 41.4 & 26.2 & 0.2 & 607.0 & 0.05 & -1.2 & 76.6 & 33.3 & 77.0 \\
\hline Ethiopia & 34.3 & 8.7 & 39.9 & 16.2 & 0.1 & 122.6 & 0.04 & -0.8 & 35.0 & 40.0 & 33.5 \\
\hline Gabon & 1.8 & 0.3 & 41.5 & 40.1 & 0.1 & 4215.5 & 0.03 & -0.5 & 92.5 & 50.0 & 68.0 \\
\hline Gambia, The & 41.4 & 17.7 & 56.2 & 13.2 & 0.1 & 317.3 & 0.06 & -0.1 & 107.1 & 52.0 & 82.5 \\
\hline Ghana & 29.1 & 9.3 & 37.2 & 16.0 & 0.1 & 249.6 & 0.21 & -0.2 & 83.9 & 50.0 & 64.5 \\
\hline Guinea & 41.8 & 15.4 & 41.8 & 15.5 & .. & 372.7 & .. & -1.2 & 50.6 & 33.3 & 65.5 \\
\hline Guinea-Bissau & 37.3 & 12.2 & 42.6 & 13.8 & 0.1 & 161.0 & 0.17 & -1.4 & 67.5 & 10.0 & 30.0 \\
\hline Kenya & 17.9 & 5.5 & 49.8 & 20.9 & 0.2 & 423.3 & 0.12 & -1.0 & 57.1 & 50.0 & 82.5 \\
\hline Lesotho & 41.9 & 20.9 & 58.4 & 9.0 & 0.1 & 478.8 & 0.09 & -0.1 & 142.4 & 50.0 & 62.0 \\
\hline Madagascar & 64.1 & 28.5 & 45.3 & 8.0 & 0.1 & 232.8 & 0.14 & -0.4 & 55.8 & 48.3 & 78.5 \\
\hline Malawi & 68.4 & 30.5 & 50.2 & 8.6 & 0.1 & 146.1 & 0.23 & -0.4 & 69.9 & 50.0 & 67.5 \\
\hline Mali & 55.8 & 25.4 & 43.2 & 10.5 & 0.1 & 210.5 & 0.03 & -0.3 & 62.3 & 45.0 & 80.0 \\
\hline Mauritania & 19.5 & 5.3 & 43.9 & 21.7 & 0.2 & 412.7 & 0.06 & -0.5 & 92.1 & 30.0 & .. \\
\hline Mozambique & 67.9 & 30.0 & 44.6 & 7.2 & 0.0 & 215.0 & 0.20 & -0.7 & 61.7 & 30.0 & 75.5 \\
\hline Namibia & 42.4 & 19.3 & 74.3 & 5.3 & .. & 1844.8 & 0.05 & 0.2 & 102.3 & 62.0 & 79.5 \\
\hline Niger & 60.0 & 23.5 & 43.0 & 9.8 & 0.1 & 157.9 & 0.04 & -0.8 & 40.4 & 35.5 & 67.0 \\
\hline Nigeria & 50.0 & 21.3 & 45.5 & 10.2 & 0.1 & 380.7 & 0.21 & -1.4 & 83.9 & 38.3 & 66.0 \\
\hline Rwanda & 66.6 & 29.8 & 46.7 & 8.4 & 0.1 & 238.7 & 0.07 & -1.0 & 35.6 & 20.0 & .. \\
\hline Senegal & 31.4 & 9.2 & 39.3 & 17.4 & 0.2 & 418.3 & 0.03 & -0.2 & 67.3 & 53.6 & 85.0 \\
\hline Sierra Leone & 41.1 & 13.5 & 42.5 & 17.9 & 0.0 & 187.2 & 0.17 & -1.3 & 50.8 & 26.0 & .. \\
\hline South Africa & 16.1 & 3.4 & 58.4 & 21.9 & 0.6 & 3092.3 & 0.07 & 0.2 & 50.3 & 50.0 & 96.5 \\
\hline Swaziland & 62.1 & 31.6 & 56.8 & 6.9 & 0.2 & 1334.5 & 0.08 & -0.6 & 172.8 & 61.7 & 81.5 \\
\hline Tanzania & 69.1 & 29.0 & 37.0 & 9.7 & 0.1 & 275.8 & 0.12 & -0.4 & 50.3 & 40.0 & 76.0 \\
\hline Togo & 25.4 & 6.2 & 34.4 & 19.8 & 0.2 & 243.8 & 0.05 & -0.9 & 74.4 & 30.0 & 82.0 \\
\hline Uganda & 47.7 & 16.7 & 43.7 & 12.2 & 0.0 & 231.9 & 0.08 & -0.7 & 35.5 & 53.3 & 83.5 \\
\hline Zambia & 52.1 & 23.6 & 49.7 & 8.8 & 0.1 & 321.2 & 0.35 & -0.6 & 60.7 & 50.0 & 79.5 \\
\hline
\end{tabular}




\section{Variable Definitions and Data Sources}

\begin{tabular}{ll}
\hline \multicolumn{1}{c}{ Variable } & \multicolumn{1}{c}{ Definition } \\
\hline Headcount index & $\begin{array}{l}\text { Headcount index is the percentage of population living in } \\
\text { households with consumption or income per person below } \\
\text { the poverty line ( } \$ 1 \text { per day). It is also called poverty } \\
\text { incidence. }\end{array}$ \\
Poverty gap & $\begin{array}{l}\text { Poverty gap is a ratio of the distance of mean shortfall from } \\
\text { the poverty line }(\$ 1 \text { a day or less) and the poverty line. It } \\
\text { characterizes how far below the poverty line the average } \\
\text { poor's income lies. }\end{array}$ \\
The Gini coefficient is the ratio of the area between \\
the Lorenz Curve, which plots share of population against \\
income share received, to the area below the diagonal. \\
It lies between 0 and 1, where 0 is perfect equality \\
and 1 is perfect inequality. \\
quintile \\
Defined as the share of income earned by the poorest quintile \\
times average income divided by 0.2 ; however, when the first \\
quintile share is not available, we assume that the distribution \\
of income is lognormal, and obtain the share of income \\
accruing to the poorest quintile as the $20^{\text {th }}$ percentile of this \\
distribution, using Gini coefficient.
\end{tabular}

Private credit over GDP Private credit by deposit money banks to GDP.

Financial Structure Database (2007), and International Financial Statistics (2007)

Financial liberalization An aggregate index capturing whether interest rates are liberalized or not, the number of years real lending and deposit rates have been positive, the existence of significant informal financial sectors and presence of directed credit allocation mechanisms.

Property rights

An index measuring the ability of individuals to accumulate WIDER database PovcalNet

Dollar and Kraay (2002), WIDER database PovcalNet

McDonald and Schumacher (2007) private property, secured by clear laws that are fully enforced by the state.

Information sharing

A dummy variable recording the presence of either public or private credit registries

Djankov, McLeish, and Shleifer (2005)

GDP per capita

Nominal gross domestic product divided by the size

IMF database of the population

Inflation

Annual change in consumer price index $(\mathrm{CPI})$

WDI database

Rule of law

A score measuring the extent to which agents have confidence in and abide by the rules of society, and in particular the

Governance Matters quality of contract enforcement, the police, and the courts, as well as the likelihood of crime and violence

(World Bank) 


\section{Robustness Tests}

Tables A2-A5 show regression results for the impact of financial development on the poor in low-income countries, for 1992-2006. These countries are: Bangladesh, Benin, Bhutan, Burkina Faso, Burundi, Cambodia, Central African Republic, Chad, Congo, Dem. Rep., Côte d'Ivoire, Ethiopia, Gambia, Ghana, Guinea-Bissau, Haiti, Kenya, Kyrgyz Republic, Lao PDR, Madagascar, Malawi, Mali, Mauritania, Mongolia, Mozambique, Nepal, Niger, Nigeria, Pakistan, Papua New Guinea, Rwanda, Senegal, Sierra Leone, Togo, Uganda, Vietnam, Yemen, Rep., and Zambia

The 12 countries underlined, about one-third of those in the sample, are in the low-income group but not in the SSA region. They contribute 27 observations, which is also about one third of the total observation points.

Tables A6-A9 show regression results for the impact of financial development on the poor in SSA countries excluding the three richest countries - Botswana, Gabon, and South Africa - for 1992-2006.

Table A1

Excluding the Rule of Law

\begin{tabular}{|c|c|c|c|c|}
\hline & \multicolumn{4}{|c|}{ Feasible Generalized Least Squares } \\
\hline & Headcount & Poverty Gap & Gini & Income \\
\hline Private Credit / GDP (log) & $\begin{array}{l}0.015 \\
(0.08)\end{array}$ & $\begin{array}{l}0.027 \\
(0.09)\end{array}$ & $\begin{array}{l}0.020 \\
(0.37)\end{array}$ & $\begin{array}{r}-0.131 \\
(0.62)\end{array}$ \\
\hline$(\text { Private Credit / GDP }(\log ))^{2}$ & $\begin{array}{l}-0.025 \\
(3.10)^{* * *}\end{array}$ & $\begin{array}{l}-0.036 \\
(3.72)^{* * *}\end{array}$ & $\begin{array}{c}-0.003 \\
(1.06)\end{array}$ & $\begin{array}{l}0.017 \\
(2.54)^{* *}\end{array}$ \\
\hline GDP per capita (\$US, log) & $\begin{array}{l}-0.434 \\
(6.85)^{* * *}\end{array}$ & $\begin{array}{l}-0.565 \\
(7.34)^{* * *}\end{array}$ & $\begin{array}{l}0.080 \\
(4.59)^{* * *}\end{array}$ & $\begin{array}{l}0.170 \\
(3.12)^{* * *}\end{array}$ \\
\hline Inflation $(\log )$ & $\begin{array}{l}0.084 \\
(0.65)\end{array}$ & $\begin{array}{l}0.497 \\
(3.22)^{* * *}\end{array}$ & $\begin{array}{l}0.156 \\
(4.68)^{* * * *}\end{array}$ & $\begin{array}{l}-0.376 \\
(4.73)^{* * *}\end{array}$ \\
\hline Trade Openness $(\log )$ & $\begin{array}{l}0.114 \\
(1.40)\end{array}$ & $\begin{array}{l}0.136 \\
(1.24)\end{array}$ & $\begin{array}{l}0.027 \\
(1.06)\end{array}$ & $\begin{array}{r}-0.116 \\
(1.58)\end{array}$ \\
\hline Property Rights (log) & $\begin{array}{r}-0.153 \\
(0.95)\end{array}$ & $\begin{array}{r}-0.206 \\
(0.84)\end{array}$ & $\begin{array}{l}0.037 \\
(0.88)\end{array}$ & $\begin{array}{l}0.079 \\
(0.48)\end{array}$ \\
\hline Interaction (lpror, lprcd) & $\begin{array}{l}-0.110 \\
(2.22)^{* *}\end{array}$ & $\begin{array}{l}-0.162 \\
(2.25)^{* *}\end{array}$ & $\begin{array}{r}-0.017 \\
(1.32)\end{array}$ & $\begin{array}{l}0.122 \\
(2.42)^{* *}\end{array}$ \\
\hline Constant & $\begin{array}{l}5.370 \\
(7.27)^{* * *}\end{array}$ & $\begin{array}{l}4.731 \\
(4.56)^{* * *}\end{array}$ & $\begin{array}{l}2.961 \\
(14.68)^{* * *}\end{array}$ & $\begin{array}{l}2.565 \\
(3.79)^{* * *}\end{array}$ \\
\hline Observations & 66 & 66 & 70 & 64 \\
\hline Number of countries & 34 & 34 & 36 & 34 \\
\hline Adjusted R2 & 0.396 & 0.428 & 0.828 & 0.730 \\
\hline Chi square (Wald test) & 301.78 & 344.65 & 851.94 & 552.80 \\
\hline
\end{tabular}

Notes: Data are averaged over five years. Absolute value of z statistics in parentheses; ${ }^{*}$ significant at $10 \% ;{ }^{* *}$ significant at $5 \%$; ${ }^{* * *}$ significant at $1 \%$. 
Table A2

Low-Income Countries - Dependent Variable: Headcount Index

Feasible Generalized Least Squares

Private Credit / GDP (log)

(Private Credit / GDP $(\log ))^{2}$

Financial Liberalization $(\log )$

GDP per capita (\$US, log)

Inflation $(\log )$

Rule of Law

Trade Openness $(\log )$

Property Rights (log)

Interaction (lpror, lpred)

Information sharing

Constant

Observations

Number of countries

Adjusted R2

Chi square (Wald test)
(1)

$\begin{array}{lc}0.307 & 0.351 \\ (2.04)^{* *} & (2.33)^{* *} \\ -0.024 & -0.021 \\ (3.11)^{* * *} & (2.93)^{* * *}\end{array}$

(2)

(3)

0.701
$(8.86)^{* * *}$
-0.330
$(1.41)$


-0.189
$(4.09)^{* * *}$
-0.524
$(3.83)^{* * *}$
-0.197
$(4.37)^{* * *}$

0.463

$(3.14)^{* * *}$

$-0.940$

$(10.03)^{* * * *}$

0.945

$(2.14)^{* *}$

(1.49)

0.073

(1.27)

$-0.217$

$(4.22)^{* * *}$

$-0.534$

$(3.91)^{* * *}$

$-0.194$

$(4.39)^{* * *}$

$(4.37)^{* * *}$

$-0.142$

(1.56)

$-0.122$

(0.73)

0.010

$(0.10)$

7.719

$(9.66)^{* * *}$

$(13.51)^{* * *}$

44

19

35

0.522

341.82
35

0.575

326.49
0.366

243.24

Notes: Data are averaged over five years. Absolute value of $\mathrm{z}$ statistics in parentheses $;{ }^{*}$ significant at $10 \% ;{ }^{* *}$ significant at $5 \% ;{ }^{* * *}$ significant at $1 \%$.

Table A3

Low-Income Countries - Dependent Variable: Poverty Gap

Feasible Generalized Least Squares

(1)

(2)

(3)

\begin{tabular}{|c|c|c|c|}
\hline Private Credit / GDP (log) & $\begin{array}{l}0.470 \\
(1.81)^{*}\end{array}$ & $\begin{array}{l}0.492 \\
(1.95)^{*}\end{array}$ & \\
\hline$(\text { Private Credit / GDP }(\log ))^{2}$ & $\begin{array}{l}-0.040 \\
(3.36)^{* * *}\end{array}$ & $\begin{array}{l}-0.037 \\
(3.23)^{* * *}\end{array}$ & \\
\hline Financial Liberalization $(\log )$ & & & $\begin{array}{l}0.658 \\
(2.65)^{* * *}\end{array}$ \\
\hline GDP per capita ( $\$$ US, log) & $\begin{array}{l}-0.975 \\
(7.65)^{* * *}\end{array}$ & $\begin{array}{l}-0.980 \\
(7.62)^{* * *}\end{array}$ & $\begin{array}{l}-1.223 \\
(8.66)^{* * *}\end{array}$ \\
\hline Inflation (log) & $\begin{array}{r}-0.220 \\
(0.46)\end{array}$ & $\begin{array}{r}-0.120 \\
(0.25)\end{array}$ & $\begin{array}{l}1.691 \\
(2.33)^{* *}\end{array}$ \\
\hline Rule of Law & $\begin{array}{l}0.057 \\
(0.53)\end{array}$ & & \\
\hline Trade Openness (log) & $\begin{array}{l}-0.357 \\
(3.81)^{* * *}\end{array}$ & $\begin{array}{l}-0.352 \\
(4.22)^{* * *}\end{array}$ & $\begin{array}{c}-0.088 \\
(0.55)\end{array}$ \\
\hline Property Rights (log) & $\begin{array}{l}-0.702 \\
(3.15)^{* * *}\end{array}$ & $\begin{array}{l}-0.673 \\
(3.07)^{* * *}\end{array}$ & $\begin{array}{r}-0.234 \\
(0.92)\end{array}$ \\
\hline Interaction (lpror, lpred) & $\begin{array}{l}-0.309 \\
(4.11)^{* * *}\end{array}$ & $\begin{array}{l}-0.305 \\
(4.05)^{* * *}\end{array}$ & \\
\hline Information sharing & & & $\begin{array}{c}-0.013 \\
(0.09)\end{array}$ \\
\hline Constant & $\begin{array}{c}10.623 \\
(9.48)^{* * *}\end{array}$ & $\begin{array}{l}10.538 \\
\mathrm{v}(9.59)^{* * *}\end{array}$ & $\begin{array}{l}7.433 \\
(5.66)^{* * *}\end{array}$ \\
\hline Observations & 73 & 73 & 44 \\
\hline Number of countries & 35 & 35 & 19 \\
\hline Adjusted R2 & 0.529 & 0.489 & 0.385 \\
\hline Chi square (Wald test) & 310.12 & 318.71 & 366.23 \\
\hline
\end{tabular}

Notes: Data are averaged over five years. Absolute value of $\mathrm{z}$ statistics in parentheses; ${ }^{*}$ significant at $10 \%{ }^{* *}$ significant at $5 \%$; ${ }^{* * *}$ significant at $1 \%$. 
Table A4

Low-Income Countries - Dependent Variable: Gini Coefficient

Feasible Generalized Least Squares

Private Credit / GDP (log)
(Private Credit / GDP $(\log ))^{2}$
Financial Liberalization (log)
GDP per capita (\$US, log)
Inflation (log)
Rule of Law
Trade Openness (log)
Property Rights (log)
Interaction (lpror, lpred)
Information sharing
Constant
Observations
Number of countries
Adjusted R2
Chi square (Wald test)

(1)

(1.62)

0.024
$(0.79)$
-0.040
$(0.33)$
-0.112
$(4.34)^{* * *}$
0.031
$(1.43)$
-0.047
$(1.28)$
-0.068
$(5.23)^{* * *}$

3.382
$(14.33)^{* * *}$
79
37
0.180
257.96

(2)

0.138
$(2.80)^{* * *}$
-0.011
$(4.58)^{* * *}$

$(4.58)^{* * *}$

(3)

0.049

$(2.14)^{* *}$

0.038

$(0.71)$

0.260

$(1.97)^{* *}$

0.026

$(0.19)$

0.013
$(0.82)$
-0.101
$(2.57)^{* *}$
-0.081
$(6.24)^{* * *}$

0.001

$(0.02)$

$-0.009$

$(0.13)$

$-0.037$

(0.99)

3.368

$\begin{array}{cc}(16.31)^{* * *} & (12.64)^{* * *} \\ 79 & 46\end{array}$

$37 \quad 20$

$0.219 \quad 0.353$

187.77

39.24

Notes: Data are averaged over five years. Absolute value of $\mathrm{z}$ statistics in parentheses $;{ }^{*}$ significant at $10 \% ;{ }^{* *}$ significant at $5 \% ;{ }^{* * *}$ significant at $1 \%$.

Table A5

Low-Income Countries - Dependent Variable: Income of the poor

\section{Feasible Generalized Least Squares}

(1)

(2)

(3)

\begin{tabular}{|c|c|c|c|}
\hline Private Credit / GDP (log) & $\begin{array}{c}-0.563 \\
(4.61)^{* * * *}\end{array}$ & $\begin{array}{l}-0.526 \\
(4.26)^{* * *}\end{array}$ & \\
\hline$(\text { Private Credit / GDP }(\log ))^{2}$ & $\begin{array}{l}0.016 \\
(2.59)^{* * *}\end{array}$ & $\begin{array}{l}0.016 \\
(2.42)^{* *}\end{array}$ & \\
\hline Financial Liberalization (log) & & & $\begin{array}{l}-0.427 \\
(5.11)^{* * *}\end{array}$ \\
\hline GDP per capita ( $\$$ US, log) & $\begin{array}{l}0.504 \\
(7.88)^{* * *}\end{array}$ & $\begin{array}{l}0.500 \\
(7.07)^{* * *}\end{array}$ & $\begin{array}{l}0.931 \\
(7.38)^{* * *}\end{array}$ \\
\hline Inflation (log) & $\begin{array}{r}-0.129 \\
(0.39)\end{array}$ & $\begin{array}{r}-0.134 \\
(0.40)\end{array}$ & $\begin{array}{c}-1.450 \\
(3.02)^{* * *}\end{array}$ \\
\hline Rule of Law & $\begin{array}{l}0.059 \\
(0.78)\end{array}$ & & \\
\hline Trade Openness (log) & $\begin{array}{l}0.122 \\
(1.96)^{*}\end{array}$ & $\begin{array}{l}0.144 \\
(2.45)^{* *}\end{array}$ & $\begin{array}{r}-0.036 \\
(0.25)\end{array}$ \\
\hline Property Rights (log) & $\begin{array}{l}0.451 \\
(3.96)^{* * *}\end{array}$ & $\begin{array}{l}0.437 \\
(3.88)^{* * *}\end{array}$ & $\begin{array}{l}0.068 \\
(0.40)\end{array}$ \\
\hline Interaction (lpror, lpred) & $\begin{array}{l}0.246 \\
(6.62)^{* * *}\end{array}$ & $\begin{array}{l}0.234 \\
(6.10)^{* * *}\end{array}$ & \\
\hline Information sharing & & & $\begin{array}{r}-0.079 \\
(0.72)\end{array}$ \\
\hline Constant & $\begin{array}{c}-1.533 \\
(2.66)^{* * * *}\end{array}$ & $\begin{array}{l}-1.598 \\
(2.94)^{* * *}\end{array}$ & $\begin{array}{r}-0.680 \\
(0.86)\end{array}$ \\
\hline Observations & 71 & 71 & 42 \\
\hline Number of countries & 35 & 35 & 19 \\
\hline Adjusted R2 & 0.705 & 0.760 & 0.605 \\
\hline Chi square (Wald test) & 378.80 & 319.41 & 140.31 \\
\hline
\end{tabular}

Notes: Data are averaged over five years. Absolute value of $\mathrm{z}$ statistics in parentheses; ${ }^{*}$ significant at $10 \% ;{ }^{* *}$ significant at $5 \% ;{ }^{* * *}$ significant at $1 \%$. 
Table A6

Excluding Outliers - Dependent Variable: Headcount Index

Feasible Generalized Least Squares

Private Credit / GDP (log)

(Private Credit / GDP $(\log ))^{2}$

Financial Liberalization (log)

GDP per capita (\$US, log)

Inflation $(\log )$

Rule of Law

Trade Openness $(\log )$

Property Rights (log)

Interaction (lpror, lprcd)

Information sharing

Constant

Observations

Number of countries

Adjusted R2

Chi square (Wald test)
(1)

$\begin{array}{cc}-0.230 & -0.243 \\ (1.38) & (1.39) \\ -0.053 & -0.053 \\ (6.44)^{* * *} & (7.35)^{* * *}\end{array}$

(2)

(3)

-0.309
$(7.49)^{* * *}$
$-0.181)^{* *}$
$(2.24)^{*}$


0.075
$(1.11)$
-0.123
$(0.98)$
-0.132
$(3.67)^{* * *}$

0.244

$(1.69)^{*}$

$-0.510$

$(6.71)^{* * *}$

0.369

$(1.86)^{*}$

(0.45)

0.130

(1.37)

0.015

$(0.20)$

$-0.198$

(1.29)

$-0.134$

$(3.51)^{* * *}$

$(3.67)^{* * *}$

$-0.173$

$(2.78)^{* * *}$

5.950

$(7.51)^{* * * *}$

$(6.35)^{* * *}$

4.329

$(6.91)^{* * *}$

0.173

$(2.86)^{* * * *}$

$-0.314$

$(2.74)^{* * *}$

62

62

53

25

31

31

0.167

0.510

0.501

1571.16

161.31

Notes: Data are averaged over five years. Absolute value of z statistics in parentheses; ${ }^{*}$ significant at $10 \% ;{ }^{* *}$ significant at $5 \% ;{ }^{* * *}$ significant at $1 \%$.

Table A7

Excluding Outliers - Dependent Variable: Poverty Gap

\begin{tabular}{|c|c|c|c|}
\hline & \multicolumn{3}{|c|}{ Feasible Generalized Least Squares } \\
\hline & (1) & (2) & (3) \\
\hline Private Credit / GDP (log) & $\begin{array}{c}-0.357 \\
(1.36)\end{array}$ & $\begin{array}{c}-0.365 \\
(1.33)\end{array}$ & \\
\hline$(\text { Private Credit / GDP }(\log ))^{2}$ & $\begin{array}{c}-0.079 \\
(6.76)^{* * *}\end{array}$ & $\begin{array}{c}-0.076 \\
(7.71)^{* * *}\end{array}$ & \\
\hline Financial Liberalization (log) & & & $\begin{array}{l}0.370 \\
(1.59)\end{array}$ \\
\hline GDP per capita (\$US, log) & $\begin{array}{c}-0.328 \\
(4.28)^{* * *}\end{array}$ & $\begin{array}{c}-0.380 \\
(6.13)^{* * *}\end{array}$ & $\begin{array}{r}-0.650 \\
(6.01)^{* * *}\end{array}$ \\
\hline Inflation (log) & $\begin{array}{l}0.151 \\
(1.07)\end{array}$ & $\begin{array}{l}0.027 \\
(0.26)\end{array}$ & $\begin{array}{l}0.611 \\
(2.02)^{* *}\end{array}$ \\
\hline Rule of Law & $\begin{array}{l}0.153 \\
(1.00)\end{array}$ & & \\
\hline Trade Openness (log) & $\begin{array}{l}0.097 \\
(0.83)\end{array}$ & $\begin{array}{l}0.170 \\
(1.43)\end{array}$ & $\begin{array}{l}0.440 \\
(4.50)^{* * *}\end{array}$ \\
\hline Property Rights (log) & $\begin{array}{r}-0.250 \\
(1.04)\end{array}$ & $\begin{array}{r}-0.136 \\
(0.67)\end{array}$ & $\begin{array}{l}-0.606 \\
(3.60)^{* * *}\end{array}$ \\
\hline Interaction (lpror, lprcd) & $\begin{array}{l}-0.196 \\
(3.50)^{* * *}\end{array}$ & $\begin{array}{l}-0.184 \\
(3.42)^{* * *}\end{array}$ & \\
\hline Information sharing & & & $\begin{array}{c}-0.392 \\
(4.25)^{* * *}\end{array}$ \\
\hline Constant & $\begin{array}{l}2.932 \\
(2.85)^{* * *}\end{array}$ & $\begin{array}{l}2.777 \\
(2.91)^{* * *}\end{array}$ & $\begin{array}{l}5.151 \\
(4.32)^{* * *}\end{array}$ \\
\hline Observations & 62 & 62 & 53 \\
\hline Number of countries & 31 & 31 & 25 \\
\hline Adjusted R2 & 0.482 & 0.329 & 0.144 \\
\hline Chi square (Wald test) & 474.83 & 535.78 & 199.69 \\
\hline
\end{tabular}

Notes: Data are averaged over five years. Absolute value of $\mathrm{z}$ statistics in parentheses; ${ }^{*}$ significant at $10 \% ;{ }^{* *}$ significant at $5 \% ;{ }^{* * *}$ significant at $1 \%$. 
Table A8

Excluding Outliers - Dependent Variable: Gini Coefficient

Feasible Generalized Least Squares

(1)

\begin{tabular}{lc}
\hline Private Credit / GDP $(\log )$ & 0.006 \\
& $(0.11)$ \\
Private Credit / GDP $(\log ))^{2}$ & -0.006 \\
& $(1.93)^{*}$ \\
Financial Liberalization $(\log )$ & \\
& \\
GDP per capita (\$US, log) & 0.074 \\
& $(3.78)^{* * *}$ \\
Inflation (log) & 0.139 \\
& $(3.08)^{* * *}$ \\
Rule of Law & 0.027 \\
& $(1.18)$ \\
Trade Openness (log) & 0.041 \\
& $(1.43)$ \\
Property Rights (log) & 0.013 \\
& $(0.27)$ \\
Interaction (lpror, lprcd) & -0.023 \\
& $(1.68)^{*}$
\end{tabular}

Information sharing

Constant

Observations

Number of countries

Adjusted R2

Chi square (Wald test)
(2)

0.000

$(0.01)$

$-0.005$

$(1.71)^{*}$

\begin{tabular}{lcc} 
& & 0.040 \\
& & $(2.22)^{* *}$ \\
0.074 & 0.075 & $0.052^{* * *}$ \\
$(3.78)^{* * *}$ & $(3.73)^{* * *}$ & $(3.01)^{* * *}$ \\
0.139 & 0.118 & 0.154 \\
$(3.08)^{* * *}$ & $(2.78)^{* * *}$ & $(3.65)^{* * *}$ \\
0.027 & & \\
$(1.18)$ & & \\
0.041 & 0.049 & 0.069 \\
$(1.43)$ & $(1.76)^{*}$ & $(2.69)^{* * *}$ \\
0.013 & 0.043 & -0.015 \\
$(0.27)$ & $(1.04)$ & $(0.31)$ \\
-0.023 & -0.019 & \\
$(1.68)^{*}$ & $(1.41)$ & -0.059 \\
& & $(1.86)^{*}$ \\
2.994 & & 3.098 \\
$(12.40)^{* * *}$ & 2.868 & $(16.23)^{* * *}$ \\
65 & $(13.46)^{* * *}$ & 56 \\
32 & 65 & 26 \\
0.543 & 32 & 0.494 \\
432.81 & 0.556 & 124.31 \\
\hline
\end{tabular}

Notes: Data are averaged over five years. Absolute value of $\mathrm{z}$ statistics in parentheses $;{ }^{*}$ significant at $10 \% ;{ }^{* *}$ significant at $5 \% ;{ }^{* * *}$ significant at $1 \%$.

Table A9

Excluding Outliers - Dependent Variable: Income of the Poor

\section{Feasible Generalized Least Squares}

(1)

(2)

(3)

\begin{tabular}{|c|c|c|c|}
\hline Private Credit / GDP (log) & $\begin{array}{c}-0.081 \\
(0.39)\end{array}$ & $\begin{array}{l}0.033 \\
(0.16)\end{array}$ & \\
\hline$(\text { Private Credit / GDP }(\log ))^{2}$ & $\begin{array}{l}0.034 \\
(3.97)^{* * *}\end{array}$ & $\begin{array}{l}0.031 \\
(4.13)^{* * *}\end{array}$ & \\
\hline Financial Liberalization (log) & & & $\begin{array}{c}-0.232 \\
(3.16)^{* * *}\end{array}$ \\
\hline GDP per capita (\$US, log) & $\begin{array}{l}0.178 \\
(2.29)^{* *}\end{array}$ & $\begin{array}{l}0.167 \\
(2.68)^{* * *}\end{array}$ & $\begin{array}{l}0.353 \\
(3.93)^{* * *}\end{array}$ \\
\hline Inflation (log) & $\begin{array}{c}-0.418 \\
(3.90)^{* * *}\end{array}$ & $\begin{array}{l}-0.211 \\
(2.48)^{* *}\end{array}$ & $\begin{array}{l}-0.492 \\
(2.84)^{* * *}\end{array}$ \\
\hline Rule of Law & $\begin{array}{l}-0.178 \\
(1.97)^{* *}\end{array}$ & & \\
\hline Trade Openness (log) & $\begin{array}{c}-0.097 \\
(1.14)\end{array}$ & $\begin{array}{l}-0.185 \\
(2.18)^{* *}\end{array}$ & $\begin{array}{l}-0.348 \\
(5.15)^{* * *}\end{array}$ \\
\hline Property Rights (log) & $\begin{array}{l}0.233 \\
(1.31)\end{array}$ & $\begin{array}{c}-0.004 \\
(0.03)\end{array}$ & $\begin{array}{l}0.389 \\
(2.48)^{* *}\end{array}$ \\
\hline Interaction (lpror, lprcd) & $\begin{array}{l}0.166 \\
(3.32)^{* * *}\end{array}$ & $\begin{array}{l}0.124 \\
(2.76)^{* * *}\end{array}$ & \\
\hline Information sharing & & & $\begin{array}{l}0.245 \\
(2.95)^{* * *}\end{array}$ \\
\hline Constant & $\begin{array}{l}2.140 \\
(2.50)^{* *}\end{array}$ & $\begin{array}{l}3.224 \\
(4.60)^{* * *}\end{array}$ & $\begin{array}{l}1.516 \\
(2.27)^{* *}\end{array}$ \\
\hline Observations & 60 & 60 & 51 \\
\hline Number of countries & 31 & 31 & 25 \\
\hline Adjusted R2 & 0.726 & 0.537 & 0.196 \\
\hline Chi square (Wald test) & 381.13 & 7778.89 & 285.59 \\
\hline
\end{tabular}

Notes: Data are averaged over five years. Absolute value of $\mathrm{z}$ statistics in parentheses; ${ }^{*}$ significant at $10 \% ;{ }^{* *}$ significant at $5 \% ;{ }^{* * *}$ significant at $1 \%$. 